\title{
Commentary \\ Phosphorylation of Kindlins and the Control of Integrin Function
}

\author{
Katarzyna Bialkowska, Jun Qin and Edward F. Plow *
}

check for

updates

Citation: Bialkowska, K.; Qin, J.; Plow, E.F. Phosphorylation of Kindlins and the Control of Integrin Function. Cells 2021, 10, 825. https:// doi.org/10.3390/cells10040825

Academic Editor: Yoshikazu Takada

Received: 5 March 2021

Accepted: 2 April 2021

Published: 7 April 2021

Publisher's Note: MDPI stays neutral with regard to jurisdictional claims in published maps and institutional affiliations.

Copyright: (c) 2021 by the authors. Licensee MDPI, Basel, Switzerland. This article is an open access article distributed under the terms and conditions of the Creative Commons Attribution (CC BY) license (https:// creativecommons.org/licenses/by/ $4.0 /)$.
Department of Cardiovascular and Metabolic Sciences, Lerner Research Institute, Cleveland Clinic, Cleveland, OH 44195, USA; bialkok@ccf.org (K.B.); qinj@ccf.org (J.Q.)

* Correspondence: plowe@ccf.org; Tel.: +1-216-445-8200

\begin{abstract}
Integrins serve as conduits for the transmission of information between cells and their extracellular environment. Signaling across integrins is bidirectional, transducing both inside-out and outside-signaling. Integrin activation, a transition from a low affinity/avidity state to a high affinity/avidity state for cognate ligands, is an outcome of inside-signaling. Such activation is particularly important for the recognition of soluble ligands by blood cells but also influences cell-cell and cell-matrix interactions. Integrin activation depends on a complex series of interactions, which both accelerate and inhibit their interconversion from the low to the high affinity/avidity state. There are three components regarded as being most proximately involved in integrin activation: the integrin cytoplasmic tails, talins and kindlins. The participation of each of these molecules in integrin activation is highly regulated by post-translation modifications. The importance of targeted phosphorylation of integrin cytoplasmic tails and talins in integrin activation is well-established, but much less is known about the role of post-translational modification of kindlins. The kindlins, a three-member family of 4.1-ezrin-radixin-moesin (FERM)-domain proteins in mammals, bind directly to the cytoplasmic tails of integrin beta subunits. This commentary provides a synopsis of the emerging evidence for the role of kindlin phosphorylation in integrin regulation.
\end{abstract}

Keywords: kindlins; phosphorylation; post-translational modifications

\section{Introduction}

Integrins, the subject of this collection, serve as primary portals of communication between cells and their extracellular environment. Information transfer across integrins is bidirectional; signaling is both inside-out and outside-in. Productive inside-out signaling results in integrin activation, a transition from a low affinity/avidity state to a high affinity/avidity state for cognate ligands. Such activation is particularly important for the recognition of soluble ligands by blood cell integrins and for certain cell-cell and cell-matrix interactions (e.g., [1-5]). While many different molecular interactions are engaged as a consequence of integrin activation leading to the formation of nascent focal adhesions and maturation into multi-molecular adhesomes [6], three molecules are now recognized as being key to and directly engaged in the activation of most integrins: (i) the integrin itself where changes are initiated in their cytoplasmic tails (CT) [7]; (ii) talin, a large cytoskeletal protein composed of a 4.1-ezrin-radixin-moesin (FERM) domain that resides in the talin head (talin-H) and a long, multi-helical bundle (the rod domain); and (iii) a kindlin, a three-member family of proteins composed of a FERM domain intersected by a PH domain [8]. Accelerants of integrin activation, such as paxillin [9,10], ADAP [11] and migfillin ([12], and inhibitors of integrin activation, such as ICAP-1 [13], filamin [14,15] and sharpin $[16,17]$, allow for fine-tuning of the integrin activation process.

Bidirectional signaling across integrins relies heavily upon post-translational modifications (PTMs) with protein phosphorylation being particularly prominent. Activation of serine, threonine and tyrosine phosphokinases are associated with ligation of integrins as is the activation of phosphatase dependent pathways. Within the integrin activation 
triumvirate of integrin $\beta \mathrm{CT}$, talin and kindlin, each component is subject phosphorylation. Both the $\alpha$ and $\beta$ CT are susceptible to phosphorylation (e.g., $[18,19])$. These PTM occur within specific motifs in the beta $\mathrm{CT}$ and are involved in the initiation, propagation and termination of outside-in and inside-out signaling. The role of integrin $\beta$ CT phosphorylation has been considered by excellent reviews [20-22]. Similarly, PTM of talin is extensive and was recognized early in the discovery of talin and its role in integrin activation $[23,24]$. The functional significance of PTM of kindlins controlling integrin signaling is now beginning to be recognized. After a brief summary of the kindlins structure, this commentary focuses on this emerging evidence that PTM of kindlins plays significant roles in integrin activation.

\subsection{Kindlin Structure and Its Role in Integrin Activation}

The three kindlins (kindlin-1 (K1), (FERMT1), kindlin-2 (K2, FERMT2) and kindlin-3 (K3, FERMT3), found in mammals are products of separate genes $[25,26]$. They are approximately $50 \%$ identical at the amino acid level and are composed of regions of high homology which are interspersed with short hypervariable regions [27]. As FERM domain proteins, each kindlin is composed of the typical F1, F2 and F3 subdomains, which is preceded by an F0 subdomain and ends in a short sequence of $\sim 8$ amino acids which is important for integrin activation by K2 [28] (see Figure 1). Distinguishing kindlins from other FERM domain proteins is the insertion of a PH domain into the F2 subdomain. The primary integrin-binding site in kindlins resides in the F3 (PTB-like) subdomain. The integrin-binding function of all three kindlins can be blunted by mutation of a QW sequence, $\mathrm{K} 1 Q W^{612}, \mathrm{~K}_{2} \mathrm{QW}{ }^{615}$ and $\mathrm{K}^{2} \mathrm{QW}{ }^{598}$ to alanines $[29,30]$. The lipid-binding properties of the PH domain and a second lipid-binding site in F0 [31,32] help to target K2 to membranes [33,34], interactions that may influence its integrin co-activator function [35-37]. $\mathrm{PH}$ domains of all three kindlins are functional lipid binding sites. The FERM domain of kindlins is most homologous to that of talin, and both bind through their F3 subdomains to the short CT of integrin beta subunits. Nevertheless, the binding sites for kindlins and talins in the integrin $\beta$ CT bring the molecules in close proximity but appear to be non-overlapping [38].

\section{T8, T30 (K1) S159, S181 Y193 (K2)}

T482,S484

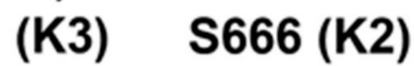

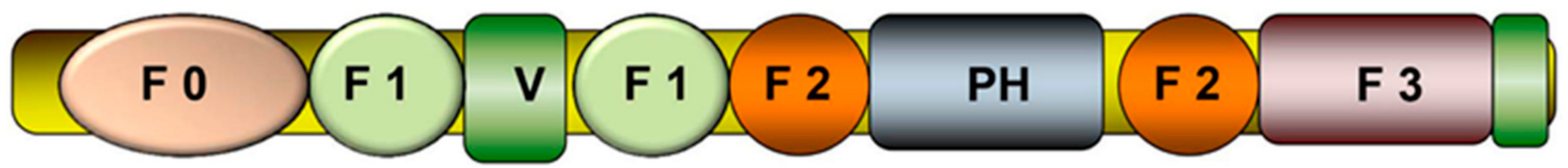

Figure 1. Domain structure of a prototypic kindlin with functionally important phosphorylation sites identified.

Kindlins are adapter proteins with many different binding partners giving rise to many different cellular responses [39,40]. The descriptions of such binding partners continue to expand but are not the topic of this review. It was originally thought that each kindlin was expressed and exerted its major effects in a tissue-specific manner [41-43]: K1 in epithelial cells, K3 in hematopoietic cells, and K2 in most other tissues. Deletion of each kindlin gene in fish, mice and/or humans is associated with significant functional impairments. To expand, deficiencies of $\mathrm{K} 1$ and $\mathrm{K} 3$ in humans have profound consequences giving rise to Kindler Syndrome, a skin fragility disorder, and LAD III, a disease associated with bleeding, susceptibility to infections and bone abnormalities [44-46]. Mice with inactivation of kindlins exhibit phenotypes that recapitulate these human diseases (K1 or $\mathrm{K} 3$ deficiencies). There is no reported deficiency of $\mathrm{K} 2$ in humans, and $\mathrm{K} 2$ gene inactivation is embryonically lethal in mice (day e7.5) and zebrafish [47,48]. However, the tissuespecific expression patterns and functions of the kindlins have blurred with the detection of individual kindlins in unexpected locations and the presence of more than one kindlin 
within the same cells $[26,49,50]$. The involvement of the different kindlins in many different cancers further blurred these demarcations. For example, K3 levels are elevated in nonmyeloid tumors such as breast cancer [51].

Crystal structures of kindlins, including their complex with integrin $\beta$ CT have been reported [52-55]. These studies have suggested that kindlins can multimerize. In the case of K2, dimerization appears to favor integrin activation [52,53] while trimerization of K3 impedes integrin activation [54]. All of these crystal structures have verified the central role of the QW motif in the F3 subdomains of the three kindlins in integrin CT binding. Biophysical studies have yielded variable results as to the significance of multimerization in integrin activation [56,57].

Several different mechanisms have been proposed as to how the binding of kindlins to beta subunits activates integrins, but consensus has yet to be reached. Ye et al. [58] used nanodiscs and concluded that talin was sufficient for integrin activation and found no effect of kindlin in this system. In studies of a $\beta 2$ integrin, Lefort et al. [59] suggested that talin led to integrin extension while kindlin-3 opened up the headpiece. Ye et al. [60] suggested that kindlins' function in integrin activation depends on their capacity to cluster integrins, i.e., the primary role of talin was to induce affinity modulation while kindlins primary role was to induce avidity modulation by clustering integrins. This model has received wide acceptance. Nevertheless, many of the same authors again concluded that talin induces extension of the integrin stalks and kindlin opens the headpiece leading to functional $\beta 2$ integrins and implicated the $\mathrm{PH}$ domain of $\mathrm{K} 3$ as essential for this pathway of integrin activation [37]. However, earlier studies found that still other domains of kindlins are involved in integrin activation $[28,61]$. The distinct roles of talin and kindlin in integrin activation were supported by the study of Theodosiou et al. [62] who found that inactivation of the genes for talin or K2 both impaired integrin function but their contribution to adhesive functions could be distinguished. The distinct role of talin and kindlin in integrin activation was also supported by correlation microscopy which showed that K2 localization to nascent adhesions preceded talin recruitment [63]. The role of kindlins in the induction of conformational change in integrin activation and in integrin clustering are not necessarily incompatible, but the mechanism by which kindlins induce integrin clustering remains to be explained. The demonstration that paxillin and ADAP interact with both kindlins and talin and may link the two integrin binding partners $[62,64]$ and allow force transmission to the cytoskeleton $[65,66]$ also needs to be integrated into a cohesive model.

\subsection{Phosphorylation of Kindlins}

Mass spectrometry and antibodies specific for phosphorylated amino acids have been used to identify a number of phosphorylation sites in each of the three kindlins. These studies were either targeted, focused on a particular kindlin or derived from global phosphoproteomic studies in specific cell types. Multiple phosphorylation sites have been identified in each of the three kindlins; and serine, threonine and tyrosine modifications have all have been identified (Table 1). To date, of the 65 phosphorylation sites, 14 have been identified in K1, 32 in K2 and 19 in K3. These are primarily pS, 38, with 15 pT and 12 pY. The modified residues reside in all major subdomains of the kindlins (Table 1). The functional significance of most of the individual phosphorylation sites remains to be established, but this is the truth for many of the phosphorylation sites in proteins. The phosphorylation sites in the kindlins occur primarily at nonconserved residues; therefore, attempts to align the phosphorylated residues in the kindlins have not been productive. To date, none of the phosphorylation sites in three kindlins has been directly implicated in oligomerization, membrane docking or interactions with known binding partners, including the binding of the phosphorylated and non-phosphorylated forms of $S^{481}$ of K3 to integrin $\beta 3$ CT [67]. 
Table 1. Phosphorylated amino acids in kindlins: Compiled from: PhosphoSitePlus ${ }^{\circledR}$ (www.phosphosite.org (accessed on 22 March 2021)).

\begin{tabular}{cccc}
\hline Domain & Kindlin-1 & Kindlin-2 & Kindlin-3 \\
\hline F0 & $\mathrm{T}^{8}, \mathrm{~S}^{11}, \mathrm{~T}^{30}$ & $\mathrm{~T}^{32}, \mathrm{~T}^{36}, \mathrm{~S}^{59}$ & $\mathrm{~T}^{6}, \mathrm{~S}^{8}, \mathrm{Y}^{11}, \mathrm{~S}^{14}, \mathrm{~S}^{31}$ \\
\hline $\mathrm{F} 1$ & $\mathrm{~S}^{169}, \mathrm{~S}^{170}, \mathrm{~S}^{174}, \mathrm{~S}^{179}, \mathrm{Y}^{191}$ & $\mathrm{~T}^{129}, \mathrm{~S}^{159}, \mathrm{~T}^{172}, \mathrm{~S}^{175}, \mathrm{~S}^{177}, \mathrm{Y}^{179}, \mathrm{~S}^{180}, \mathrm{~S}^{181}$, & $\mathrm{Y}^{162}, \mathrm{~S}^{218}$ \\
$\mathrm{Y}$ & $\mathrm{Y}^{185}, \mathrm{~S}^{186}, \mathrm{~T}^{192}, \mathrm{Y}^{193}, \mathrm{~S}^{199}, \mathrm{~T}^{205}, \mathrm{~S}^{258}$ & $\mathrm{~S}^{337}, \mathrm{~S}^{345}, \mathrm{~T}^{361}, \mathrm{~S}^{428}$, \\
$\mathrm{T}^{482}, \mathrm{~S}^{484}$, & $\mathrm{Y}^{504}$ \\
$\mathrm{~F}$ F3 & $\mathrm{S}^{361}, \mathrm{Y}^{392}, \mathrm{Y}^{452}$ & $\mathrm{~S}^{339}, \mathrm{~S}^{351}, \mathrm{Y}^{378}, \mathrm{Y}^{395}, \mathrm{~S}^{405}, \mathrm{~S}^{414}$, & $\mathrm{T}^{416}, \mathrm{~S}^{435}$ \\
\hline
\end{tabular}

The eight phosphorylation sites in kindlins depicted in Figure 1 have been assigned specific functions, and we discuss these briefly below. In K1, a particular function has been assigned to $\mathrm{T}^{8}$ and $\mathrm{T}^{30}$ within the $\mathrm{F} 0$ subdomain in the regulation of mitotic spindles [68]. Orientation of mitotic spindles is known to be regulated by $\beta 1$-integrins, and disruption of $\mathrm{K} 1$ mimics the effect of the $\beta 1$-integrin depletion on spindle phenotype. $\mathrm{K} 1$ is exclusively phosphorylated by Plk1 at centrosomes. While K1 phosphorylation of $\mathrm{T}^{8}$ and $\mathrm{T}^{30}$ is pivotal for normal spindle formation, these PTM are not required for integrin activation as demonstrated using a phosphorylation resistant $\mathrm{K} 1^{\mathrm{T} 8 \mathrm{~T} 30 / \mathrm{AA}}$ mutant. $\mathrm{K} 2$ has also been shown to control mitotic spindle assembly through a mechanism distinct from that of K1 and depends on $\alpha$-tubulin acetylation, AKT serine/threonine kinase or paxillin [69].

Several functionally important phosphorylation sites have been identified in K2 (Figure 1). Cell adhesion-dependent K2-Src interaction and phosphorylation of K2 on $\mathrm{Y}^{193}$ by Src was shown to be an important event in regulating integrin outside-in signaling which controls cell migration and proliferation. Focal adhesion kinase-induced recruitment of Src to focal adhesions leads to Src activation and K2 phosphorylation and in turn regulates tyrosine phosphorylation of paxillin and cell behavior [70]. K2 phosphorylation on $\mathrm{Y}^{193}$ also promotes recruitment of migfilin to focal adhesion, and this event plays an important role in regulation of Src activity in focal adhesions [71]. K2 phosphorylation was also shown to be important in the regulation of invadopodia formation and protease-induced remodeling of extracellular matrix in cancer cells [72]. Phosphoproteomic analyses of breast cancer cell line MDA-MB-231 plated on invadopodia-inducing dense fibrillar collagen identified several K2 phosphorylation sites: $S^{159}, S^{181}$ and $S^{666}$. Mutation of these serines to alanines inhibited the formation of invadopodia in MDA-231 cells on dense fibrillary collagen; conversely, phospho-mimetic mutants stimulated the formation of invadopodia even on low-density collagen [72]. In colorectal cancer, $\mathrm{K} 2$ is phosphorylated on $\mathrm{S}^{159}$ by serine/threonine kinase IkB kinase subunit epsilon (IKKe), and K2 phosphorylation-promoted invadopodia formation and metastasis of colorectal cancer [73].

Agonist-induced $\mathrm{K} 3$ phosphorylation on $\mathrm{T}^{482}$ or $\mathrm{S}^{484}$, which reside in a hyper-variable region of K3, was first identified in hematopoietic cells including human platelets, human erythroleukemia HEL cells and mouse macrophage-like RAW 267.4 cells [67]. Phosphorylation of K3 in hematopoietic cells affected both inside-out and outside-in integrin signaling across $\alpha \mathrm{IIb} \beta 3$ and $\alpha 5 \beta 1$ integrins, and affected specific functions of K3 [74]. Two independent studies implicated protein kinase $C$ in phosphorylation of these residues $[67,75]$ although there is some ambiguity as to which residue is modified. An antibody specific for $\mathrm{pS}^{484}$ reacted with agonist-stimulated platelets and HEL cells, whereas an antibody to $\mathrm{pT}^{482}$ did not [74]. However, phosphorylation of $\mathrm{T}^{482}$ was identified in the $\mathrm{T}$ lymphocyte Jurkat cell line [76]. In neutrophils, K3 phosphorylation of $S^{484}$ was dependent on integrin-linked kinase binding to $\mathrm{K} 3$, and $\mathrm{K} 3$ phosphorylation was crucial for $\alpha \mathrm{L} \beta 2$-induced neutrophil adhesion and recruitment [75]. K3 phosphorylation on $\mathrm{T}^{482}$ and /or $\mathrm{S}^{484}$ is also critical for its function as a tumor promoter in breast cancer cells, where $\mathrm{K} 3$ and its phosphorylation contributed to its tumor promoter activity [74]. 


\section{Other Post-Translational Modifications of Kindlins and Concluding Remarks}

The importance of phosphorylation in controlling the functions of kindlins and their role in integrin activation is just beginning to be recognized. It remains to be seen if phosphorylation of individual residues differs in different cell types and exerts cell-specific effects. This is likely to mark the next step in this emerging area. This commentary focused on phosphorylation per se but other PTM of kindlins can also be anticipated. One such PTM, ubiquitination of K2, which has functional consequences, has already been reported [77]. Talin also has been reported to be a target of ubiquitination [78] although this result was not reproduced [77]. Other ubiquinylation sites are predicted in the kindlins (see PhosphoSitePlus ${ }^{\circledR}$ (www.phosphosite.org, accessed on 22 March 2021)). The proteolysis of kindlins represents another line of PTM. Calpain-induced cleavage of $\mathrm{K} 3$ in leukocytes was reported [79], and, in general, kindlins appear to be sensitive to proteolysis in cells providing another level of regulation. Thus, we anticipate that the PTM of kindlins identified in this commentary is likely to be harbingers of others to come.

Author Contributions: Conceptualization, E.F.P. and K.B. Drafting and editing of manuscript, E.F.P., J.Q. and K.B. All authors have read and agreed to the published version of the manuscript.

Funding: This research was funded by NIH grant HL096062.

Institutional Review Board Statement: Not applicable.

Informed Consent Statement: Not applicable.

Data Availability Statement: All data are available in publically available databases or upon request to E.F.P.

Acknowledgments: This work was supported in part by NIH grant HL096062.

Conflicts of Interest: The authors declare no conflict of interest.

\section{References}

1. Ginsberg, M.H.; Du, X.; Plow, E.F. Inside-out signalling. Curr. Opin. Cell Biol. 1992, 4, 766-771. [CrossRef]

2. Li, Z.; Delaney, M.K.; O’Brien, K.A.; Du, X. Signaling During Platelet Adhesion and Activation. Arter. Thromb. Vasc. Biol. 2010, 30, 2341-2349. [CrossRef] [PubMed]

3. Durrant, T.N.; van den Bosch, M.T.; Hers, I. Integrin alphaIlbbeta3 outside-in signaling. Blood 2017, 130, 1607-1619. [CrossRef] [PubMed]

4. Ginsberg, M.H. Integrin activation. BMB Rep. 2014, 47, 655-659. [CrossRef]

5. Humphries, J.D.; Chastney, M.R.; A Askari, J.; Humphries, M.J. Signal transduction via integrin adhesion complexes. Curr. Opin. Cell Biol. 2019, 56, 14-21. [CrossRef]

6. Horton, E.R.; Byron, A.; Askari, J.A.; Ng, D.H.J.; Millon-Frémillon, A.; Robertson, J.; Koper, E.J.; Paul, N.R.; Warwood, S.; Knight, D.P.; et al. Definition of a consensus integrin adhesome and its dynamics during adhesion complex assembly and disassembly. Nat. Cell Biol. 2015, 17, 1577-1587. [CrossRef]

7. Vinogradova, O.; Velyvis, A.; Velyviene, A.; Hu, B.; Haas, T.A.; Plow, E.F.; Qin, J. A structural mechanism of integrin aIlbb3 "inside-out" activation as regulated by its cytoplasmic face. Cell 2002, 110, 587-597. [CrossRef]

8. Zhu, L.; Plow, E.F.; Qin, J. Initiation of focal adhesion assembly by talin and kindlin: A dynamic view. Protein Sci. 2021, 30, 531-542. [CrossRef]

9. Zhu, L.; Liu, H.; Lu, F.; Yang, J.; Byzova, T.V.; Qin, J. Structural Basis of Paxillin Recruitment by Kindlin-2 in Regulating Cell Adhesion. Structure 2019, 27, 1686-1697.e5. [CrossRef]

10. Gao, J.; Huang, M.; Lai, J.; Mao, K.; Sun, P.; Cao, Z.; Hu, Y.; Zhang, Y.; Schulte, M.L.; Jin, C.; et al. Kindlin supports platelet integrin alphaIlbbeta3 activation by interacting with paxillin. J. Cell Sci. 2017, 130, 3764-3775. [CrossRef]

11. Kasirer-Friede, A.; Kang, J.; Kahner, B.; Ye, F.; Ginsberg, M.H.; Shattil, S.J. ADAP interactions with talin and kindlin promote platelet integrin alphaIlbbeta3 activation and stable fibrinogen binding. Blood 2014, 20, 3156-3165. [CrossRef]

12. Das, M.; Ithychanda, S.S.; Qin, J.; Plow, E.F. Migfilin and Filamin as Regulators of Integrin Activation in Endothelial Cells and Neutrophils. PLoS ONE 2011, 6, e26355. [CrossRef]

13. Bouvard, D.; Aszodi, A.; Kostka, G.; Block, M.R.; Albigès-Rizo, C.; Fässler, R. Defective osteoblast function in ICAP-1-deficient mice. Development 2007, 134, 2615-2625. [CrossRef]

14. Ithychanda, S.S.; Qin, J. Evidence for Multisite Ligand Binding and Stretching of Filamin by Integrin and Migfilin. Biochemistry 2011, 50, 4229-4231. [CrossRef] 
15. Liu, J.; Das, M.; Yang, J.; Ithychanda, S.S.; Yakubenko, V.P.; Plow, E.F.; Qin, J. Structural mechanism of integrin inactivation by filamin. Nat. Struct. Mol. Biol. 2015, 22, 383-389. [CrossRef]

16. Rantala, J.K.; Pouwels, J.; Pellinen, T.; Veltel, S.; Laasola, P.; Mattila, E.; Potter, C.S.; Duffy, T.; Sundberg, J.P.; Kallioniemi, O.; et al. SHARPIN is an endogenous inhibitor of beta1-integrin activation. Nat. Cell Biol. 2011, 13, 1315-1324. [CrossRef]

17. Gao, J.; Bao, Y.; Ge, S.; Sun, P.; Sun, J.; Liu, J.; Chen, F.; Han, L.; Cao, Z.; Qin, J.; et al. Sharpin suppresses beta1-integrin activation by complexing with the beta1 tail and kindlin-1. Cell Commun. Signal. 2019, 17, 101. [CrossRef]

18. Han, J.; Rose, D.M.; Woodside, D.G.; Goldfinger, L.E.; Ginsberg, M.H. Integrin alpha 4 beta 1-dependent T cell migration requires both phosphorylation and dephosphorylation of the alpha 4 cytoplasmic domain to regulate the reversible binding of paxillin. $J$. Biol. Chem. 2003, 278, 34845-34853. [CrossRef]

19. Jenkins, A.L.; Nannizzi-Alaimo, L.; Silver, D.; Sellers, J.R.; Ginsberg, M.H.; Law, D.A.; Phillips, D.R. Tyrosine phosphorylation of the b3 cytoplasmic domain mediates integrin-cytoskeletal interactions. J. Biol. Chem. 1998, 273, 13878-13885. [CrossRef]

20. Gahmberg, C.G.; Gronholm, M.; Uotila, L.M. Regulation of integrin activity by phosphorylation. Adv. Exp. Med. Biol. 2014, 819, 85-96.

21. Phillips, D.R.; Nannizzi-Alaimo, L.; Prasad, K.S. Beta3 tyrosine phosphorylation in alphaIlbbeta3 (platelet membrane GP IIb-IIIa) outside-in integrin signaling. Thromb. Haemost. 2001, 86, 246-258.

22. Mitra, S.K.; Schlaepfer, D.D. Integrin-regulated FAK-Src signaling in normal and cancer cells. Curr. Opin. Cell Biol. 2006, 18, 516-523. [CrossRef]

23. Turner, E.C.; Pavalko, F.M.; Burridge, K. The role of phosphorylation and limited proteolytic cleavage of talin and vinculin in the disruption of focal adhesion integrity. J. Biol. Chem. 1989, 264, 11938-11944. [CrossRef]

24. Ratnikov, B.; Ptak, C.; Han, J.; Shabanowitz, J.; Hunt, D.F.; Ginsberg, M.H. Talin phosphorylation sites mapped by mass spectrometry. J. Cell Sci. 2005, 118, 4921-4923. [CrossRef]

25. Larjava, H.; Plow, E.F.; Wu, C. Kindlins: Essential regulators of integrin signalling and cell-matrix adhesion. EMBO Rep. 2008, 9 , 1203-1208. [CrossRef]

26. Rognoni, E.; Ruppert, R.; Fässler, R. The kindlin family: Functions, signaling properties and implications for human disease. J. Cell Sci. 2016, 129, 17-27. [CrossRef]

27. Malinin, N.L.; Plow, E.F.; Byzova, T.V. Kindlins in FERM adhesion. Blood 2010, 115, 4011-4017. [CrossRef]

28. Hirbawi, J.; Bialkowska, K.; Bledzka, K.M.; Liu, J.; Fukuda, K.; Qin, J.; Plow, E.F. The extreme C-terminal region of kindlin-2 is critical to its regulation of integrin activation. J. Biol. Chem. 2017, 292, 14258-14269. [CrossRef]

29. Shi, X.; Ma, Y.-Q.; Tu, Y.; Chen, K.; Wu, S.; Fukuda, K.; Qin, J.; Plow, E.F.; Wu, C. The MIG-2/Integrin Interaction Strengthens Cell-Matrix Adhesion and Modulates Cell Motility. J. Biol. Chem. 2007, 282, 20455-20466. [CrossRef]

30. Rensen, S.S.M.; Doevendans, P.A.F.M.; Van Eys, G.J.J.M. Regulation and characteristics of vascular smooth muscle cell phenotypic diversity. Neth. Hearth J. 2007, 15, 100-108. [CrossRef]

31. Qu, H.; Tu, Y.; Shi, X.; Larjava, H.; Saleem, M.A.; Shattil, S.J.; Fukuda, K.; Qin, J.; Kretzler, M.; Wu, C. Kindlin-2 regulates podocyte adhesion and fibronectin matrix deposition through interactions with phosphoinositides and integrins. J. Cell Sci. 2011, 124, 879-891. [CrossRef] [PubMed]

32. Perera, D.; Ma, Y.-Q.; Yang, J.; Hirbawi, J.; Plow, E.F.; Qin, J. Membrane Binding of the N-Terminal Ubiquitin-Like Domain of Kindlin-2 Is Crucial for Its Regulation of Integrin Activation. Structure 2011, 19, 1664-1671. [CrossRef] [PubMed]

33. Liu, J.; Fukuda, K.; Xu, Z.; Ma, Y.-Q.; Hirbawi, J.; Mao, X.; Wu, C.; Plow, E.F.; Qin, J. Structural Basis of Phosphoinositide Binding to Kindlin-2 Protein Pleckstrin Homology Domain in Regulating Integrin Activation. J. Biol. Chem. 2011, 286, 43334-43342. [CrossRef] [PubMed]

34. Liu, Y.; Zhu, Y.; Ye, S.; Zhang, R. Crystal structure of kindlin-2 PH domain reveals a conformational transition for its membrane anchoring and regulation of integrin activation. Protein Cell 2012, 3, 434-440. [CrossRef]

35. Metcalf, D.G.; Moore, D.T.; Wu, Y.; Kielec, J.M.; Molnar, K.; Valentine, K.G.; Wand, A.J.; Bennett, J.S.; DeGrado, W.F. NMR analysis of the alphaIIb beta3 cytoplasmic interaction suggests a mechanism for integrin regulation. Proc. Natl. Acad. Sci. USA 2010, 107, 22481-22486. [CrossRef]

36. Hart, R.; Stanley, P.; Chakravarty, P.; Hogg, N. The Kindlin 3 Pleckstrin Homology Domain Has an Essential Role in Lymphocyte Function-associated Antigen 1 (LFA-1) Integrin-mediated B Cell Adhesion and Migration. J. Biol. Chem. 2013, 288, 14852-14862. [CrossRef]

37. Wen, L.; Marki, A.; Roy, P.; McArdle, S.; Sun, H.; Fan, Z.; Gingras, A.R.; Ginsberg, M.H.; Ley, K. Kindlin-3 recruitment to the plasma membrane precedes high affinity beta2 integrin and neutrophil arrest from rolling. Blood 2021, 137, 29-38. [CrossRef]

38. Bledzka, K.; Liu, J.; Xu, Z.; Perera, H.D.; Yadav, S.P.; Bialkowska, K.; Qin, J.; Ma, Y.; Plow, E.F. Spatial coordination of kindlin-2 with talin head domain in interaction with integrin beta cytoplasmic tails. J. Biol. Chem. 2012, 287, 24585-24594. [CrossRef]

39. Plow, E.F.; Das, M.; Bialkowska, K.; Sossey-Alaoui, K. Of Kindlins and Cancer. Discoveries 2016, 4, e59. [CrossRef]

40. Plow, E.F.; Qin, J. The Kindlin Family of Adapter Proteins. Circ. Res. 2019, 124, 202-204. [CrossRef]

41. Ussar, S.; Wang, H.-V.; Linder, S.; Fässler, R.; Moser, M. The Kindlins: Subcellular localization and expression during murine development. Exp. Cell Res. 2006, 312, 3142-3151. [CrossRef]

42. Meves, A.; Stremmel, C.; Gottschalk, K.; Fässler, R. The Kindlin protein family: New members to the club of focal adhesion proteins. Trends Cell Biol. 2009, 19, 504-513. [CrossRef]

43. Karaköse, E.; Schiller, H.B.; Fässler, R. The kindlins at a glance. J. Cell Sci. 2010, 123, 2353-2356. [CrossRef] 
44. Ussar, S.; Moser, M.; Widmaier, M.; Rognoni, E.; Harrer, C.; Genzel-Boroviczény, O.; Fässler, R. Loss of Kindlin-1 Causes Skin Atrophy and Lethal Neonatal Intestinal Epithelial Dysfunction. PLoS Genet. 2008, 4, e1000289. [CrossRef]

45. Moser, M.; Nieswandt, B.; Ussar, S.; Pozgajova, M.; Fässler, R. Kindlin-3 is essential for integrin activation and platelet aggregation. Nat. Med. 2008, 14, 325-330. [CrossRef]

46. Malinin, N.L.; Pluskota, E.; Byzova, T.V. Integrin signaling in vascular function. Curr. Opin. Hematol. 2012, 19, 206-211. [CrossRef]

47. Montanez, E.; Ussar, S.; Schifferer, M.; Bösl, M.; Zent, R.; Moser, M.; Fässler, R. Kindlin-2 controls bidirectional signaling of integrins. Genes Dev. 2008, 22, 1325-1330. [CrossRef]

48. Dowling, J.J.; Gibbs, E.; Russell, M.; Goldman, D.; Minarcik, J.; Golden, J.A.; Feldman, E.L. Kindlin-2 Is an Essential Component of Intercalated Discs and Is Required for Vertebrate Cardiac Structure and Function. Circ. Res. 2008, 102, 423-431. [CrossRef]

49. Bialkowska, K.; Ma, Y.-Q.; Bledzka, K.; Sossey-Alaoui, K.; Izem, L.; Zhang, X.; Malinin, N.; Qin, J.; Byzova, T.; Plow, E.F. The Integrin Co-activator Kindlin-3 Is Expressed and Functional in a Non-hematopoietic Cell, the Endothelial Cell. J. Biol. Chem. 2010, 285, 18640-18649. [CrossRef]

50. Harburger, D.S.; Bouaouina, M.; Calderwood, D.A. Kindlin-1 and -2 directly bind the C-terminal region of beta integrin cytoplasmic tails and exert integrin-specific activation effects. J. Biol. Chem 2009, 284, 11485-11497. [CrossRef]

51. Sossey-Alaoui, K.; Pluskota, E.; Davuluri, G.; Bialkowska, K.; Das, M.; Szpak, D.; Lindner, D.J.; Downs-Kelly, E.; Thompson, C.L.; Plow, E.F. Kindlin-3 enhances breast cancer progression and metastasis by activating Twist-mediated angiogenesis. FASEB J. 2014, 28, 2260-2271. [CrossRef]

52. Li, H.; Deng, Y.; Sun, K.; Yang, H.; Liu, J.; Wang, M.; Zhang, Z.; Lin, J.; Wu, C.; Wei, Z.; et al. Structural basis of kindlin-mediated integrin recognition and activation. Proc. Natl. Acad. Sci. USA 2017, 114, 9349-9354. [CrossRef]

53. Sun, J.; Xiao, D.; Ni, Y.; Zhang, T.; Cao, Z.; Xu, Z.; Nguyen, H.; Zhang, J.; White, G.C.; Ding, J.; et al. Structure basis of the FERM domain of kindlin-3 in supporting integrin alphaIlbbeta3 activation in platelets. Blood Adv. 2020, 4, 3128-3135. [CrossRef]

54. Bu, W.; Levitskaya, Z.; Loh, Z.Y.; Jin, S.; Basu, S.; Ero, R.; Yan, X.; Wang, M.; Ngan, S.F.C.; Sze, S.K.; et al. Structural basis of human full-length kindlin-3 homotrimer in an auto-inhibited state. PLoS Biol. 2020, 18, e3000755. [CrossRef]

55. Yates, L.A.; Lumb, C.N.; Brahme, N.N.; Zalyte, R.; Bird, L.E.; De Colibus, L.; Owens, R.J.; Calderwood, D.A.; Sansom, M.S.P.; Gilbert, R.J.C. Structural and Functional Characterization of the Kindlin-1 Pleckstrin Homology Domain. J. Biol. Chem. 2012, 287, 43246-43261. [CrossRef]

56. Yates, L.A.; Füzéry, A.K.; Bonet, R.; Campbell, I.D.; Gilbert, R.J.C. Biophysical analysis of Kindlin-3 reveals an elongated conformation and maps integrin binding to the membrane-distal beta-subunit NPXY motif. J. Biol. Chem. 2012, 287, 37715-37731. [CrossRef]

57. Kadry, Y.A.; Maisuria, E.M.; Huet-Calderwood, C.; Calderwood, D.A. Differences in self-association between kindlin-2 and kindlin-3 are associated with differential integrin binding. J. Biol. Chem. 2020, 295, 11161-11173. [CrossRef]

58. Ye, F.; Hu, G.; Taylor, D.; Ratnikov, B.; Bobkov, A.A.; McLean, M.A.; Sligar, S.G.; Taylor, K.A.; Ginsberg, M.H. Recreation of the terminal events in physiological integrin activation. J. Cell Biol. 2010, 188, 157-173. [CrossRef] [PubMed]

59. Lefort, C.T.; Rossaint, J.; Moser, M.; Petrich, B.G.; Zarbock, A.; Monkley, S.J.; Critchley, D.R.; Ginsberg, M.H.; Fässler, R.; Ley, K Distinct roles for talin-1 and kindlin-3 in LFA-1 extension and affinity regulation. Blood 2012, 119, 4275-4282. [CrossRef] [PubMed]

60. Ye, F.; Petrich, B.G.; Anekal, P.; Lefort, C.T.; Kasirer-Friede, A.; Shattil, S.J.; Moser, M.; Fässler, R.; Ginsberg, M.H. The mechanism of kindlin-mediated activation of integrin alphaIlbbeta3. Curr. Biol. 2013, 23, 2288-2295. [CrossRef]

61. Xu, Z.; Gao, J.; Hong, J.; Ma, Y.-Q. Integrity of kindlin-2 FERM subdomains is required for supporting integrin activation. Biochem. Biophys. Res. Commun. 2013, 434, 382-387. [CrossRef] [PubMed]

62. Theodosiou, M.; Widmaier, M.; Böttcher, R.T.; Rognoni, E.; Veelders, M.; Bharadwaj, M.; Lambacher, A.; Austen, K.; Müller, D.J.; Zent, R.; et al. Kindlin-2 cooperates with talin to activate integrins and induces cell spreading by directly binding paxillin. eLife 2016, 5, e10130. [CrossRef] [PubMed]

63. Bachir, A.I.; Zareno, J.; Moissoglu, K.; Plow, E.F.; Gratton, E.; Horwitz, A.R. Integrin-Associated Complexes Form Hierarchically with Variable Stoichiometry in Nascent Adhesions. Curr. Biol. 2014, 24, 1845-1853. [CrossRef] [PubMed]

64. Kasirer-Friede, A.; Moran, B.; Nagrampa-Orje, J.; Swanson, K.; Ruggeri, Z.M.; Schraven, B.; Neel, B.G.; Koretzky, G.; Shattil, S.J. ADAP is required for normal alphaIlbbeta3 activation by VWF/GP Ib-IX-V and other agonists. Blood 2007, 109, 1018-1025. [CrossRef]

65. Nordenfelt, P.; Elliott, H.L.; Springer, T.A. Coordinated integrin activation by actin-dependent force during T-cell migration. Nat. Commun. 2016, 7, 13119. [CrossRef]

66. Goult, B.T.; Yan, J.; Schwartz, M.A. Talin as a mechanosensitive signaling hub. J. Cell Biol. 2018, 217, 3776-3784. [CrossRef]

67. Bialkowska, K.; Byzova, T.V.; Plow, E.F. Site-specific phosphorylation of kindlin-3 protein regulates its capacity to control cellular responses mediated by integrin alphaIlbbeta3. J. Biol. Chem. 2015, 290, 6226-6242. [CrossRef]

68. Patel, H.; Zich, J.; Serrels, B.; Rickman, C.; Hardwick, K.G.; Frame, M.C.; Brunton, V.G. Kindlin-1 regulates mitotic spindle formation by interacting with integrins and Plk-1. Nat. Commun. 2013, 4, 2056. [CrossRef]

69. Tan, H.-F.; Tan, S.-M. The focal adhesion protein kindlin-2 controls mitotic spindle assembly by inhibiting histone deacetylase 6 and maintaining $\alpha$-tubulin acetylation. J. Biol. Chem. 2020, 295, 5928-5943. [CrossRef]

70. Qu, H.; Tu, Y.; Guan, J.-L.; Xiao, G.; Wu, C. Kindlin-2 Tyrosine Phosphorylation and Interaction with Src Serve as a Regulatable Switch in the Integrin Outside-in Signaling Circuit. J. Biol. Chem. 2014, 289, 31001-31013. [CrossRef] 
71. Liu, Z.; Lu, D.; Wang, X.; Wan, J.; Liu, C.; Zhang, H. Kindlin-2 phosphorylation by Src at Y193 enhances Src activity and is involved in Migfilin recruitment to the focal adhesions. FEBS Lett. 2015, 589, 2001-2010. [CrossRef]

72. Artym, V.V.; Swatkoski, S.; Matsumoto, K.; Campbell, C.B.; Petrie, R.J.; Dimitriadis, E.K.; Li, X.; Mueller, S.C.; Bugge, T.H.; Gucek, M.; et al. Dense fibrillar collagen is a potent inducer of invadopodia via a specific signaling network. J. Cell Biol. 2015, 208, 331-350. [CrossRef]

73. Liu, G.; Bao, Y.; Liu, C.; Zhu, Q.; Zhao, L.; Lu, X.; Zhu, Q.; Lv, Y.; Bai, F.; Wen, H. IKKepsilon phosphorylates kindlin-2 to induce invadopodia formation and promote colorectal cancer metastasis. Theranostics 2020, 10, 2358-2373. [CrossRef]

74. Bialkowska, K.; Sossey-Alaoui, K.; Pluskota, E.; Izem, L.; Qin, J.; Plow, E.F. Site-specific phosphorylation regulates the functions of kindlin-3 in a variety of cells. Life Sci. Alliance 2019, 3, e201900594. [CrossRef]

75. Margraf, A.; Germena, G.; Drexler, H.C.A.; Rossaint, J.; Ludwing, N.; Prystaj, B.; Mersamann, S.; Thomas, K.; Block, H.; Gottschilch, W.; et al. The integrin linked kinase is required for chemokine-triggered high affinity conformation of neutrophil beta2-integrin LFA1. Blood 2020, 136, 2200-2205. [CrossRef]

76. Ruperez, P.; Gago-Martinez, A.; Burlingame, A.L.; Oses-Prieto, J.A. Quantitative Phosphoproteomic Analysis Reveals a Role for Serine and Threonine Kinases in the Cytoskeletal Reorganization in Early T Cell Receptor Activation in Human Primary T Cells. Mol. Cell. Proteom. 2012, 11, 171-186. [CrossRef]

77. Wei, X.; Wang, X.; Zhan, J.; Chen, Y.; Fang, W.; Zhang, L.; Zhang, H. Smurf1 inhibits integrin activation by controlling Kindlin-2 ubiquitination and degradation. J. Cell Biol. 2017, 216, 1455-1471. [CrossRef]

78. Huang, C.; Rajfur, Z.; Yousefi, N.; Chen, Z.; Jacobson, K.; Ginsberg, M.H. Talin phosphorylation by Cdk5 regulates Smurf1mediated talin head ubiquitylation and cell migration. Nat. Cell Biol. 2009, 11, 624-630. [CrossRef]

79. Zhao, Y.; Malinin, N.L.; Meller, J.; Ma, Y.; West, X.Z.; Bledzka, K.; Qin, J.; Podrez, E.A.; Byzova, T.V. Regulation of Cell Adhesion and Migration by Kindlin-3 Cleavage by Calpain. J. Biol. Chem. 2012, 287, 40012-40020. [CrossRef] 